\title{
Effect of size grading on sea bass (Dicentrarchus labrax) juvenile self-feeding behaviour, social structure and culture performance
}

\author{
David Benhaïm ${ }^{1, a}$, Samuel Péan ${ }^{2}$, Blandine Brisset ${ }^{2}$, Didier Leguay ${ }^{2}$, \\ Marie-Laure Bégout ${ }^{2}$ and Béatrice Chatain ${ }^{3}$ \\ 1 LERMA, INTECHMER/CNAM, BP 324, 50103 Cherbourg Cedex, France \\ 2 IFREMER, place Gaby Coll, BP 7, 17137 L'Houmeau, France \\ 3 Station expérimentale d'Aquaculture Ifremer, Laboratoire de Recherche piscicole de Méditerranée, chemin de Maguelone, \\ 34250 Palavas-les-Flots, France
}

Received 30 March 2011; Accepted 24 July 2011

\begin{abstract}
This study aims to test the influence of size grading on self-feeding behaviour, social structure (measured by the percentage of triggering acts per individual), growth performances, and blood physiological variables of individually passive integrated transponder (PIT)-tagged sea bass juveniles, using a computerized on-demand feeding system coupled with a PIT tag monitoring device. Three consecutive periods of 27 days each were compared: a first period $(P 1)$ before grading $(6$ tanks of $100 \mathrm{fish} ; 40.2 \pm 8.9 \mathrm{~g})$ followed by a second period $(P 2)$ after grading. The protocol applied aimed to create two groups of fish of similar mean weight but with either a low or a high coefficient of variation of weight $\left(C V_{\mathrm{w}}\right)$ corresponding to an imposed difference in social disruption $\left(T_{\text {low }}: C V_{\mathrm{w}} \sim 10 \%, 3\right.$ tanks of 60 fish each with social disruption; $T_{\text {high: }} C V_{\mathrm{w}} \sim 20 \%, 3$ tanks of 60 fish each, without social disruption). $T_{\text {low }}$ and $T_{\text {high }}$ groups were studied over $P 2$, and an additional 27-day period under identical conditions ( $P 3$ ). The grading protocol used and/or time modified the social structure when comparing $P 1$ and $P 2$. Thereafter, during $P 2$ and $P 3$, no difference could be observed in growth performances, feed demand, or physiological variables between $T_{\text {low }}$ and $T_{\text {high }}$ groups. Feeding rhythms and social structures were similar in both groups. In conclusion, such grading practice only transiently modifies feed demand behaviour and social structure built around the self-feeder, without further improvement in individual growth performances in sea bass.
\end{abstract}

Key words: Feeding behaviour / Self feeder / Triggering activity / Heterogeneity / Growth / Grading

\section{Introduction}

Variation in individual growth is a common feature in many cultured fish stocks (Huntingford et al. 1990; Stefánsson et al. 2000; Smith and Fuiman 2003). Magnuson (1962) defined growth depensation as the increase in the variance of size distribution over time, due to differences in growth rates. Such variation is generally considered as a drawback in commercial fish culture (Barki et al. 2000). Indeed good aquaculture practices usually aim to minimize growth depensation to reduce food wastage, and water quality degradation. Even though growth heterogeneity has been extensively studied in both natural and cultured fish population, it remains a central problem in aquaculture.

Kestemont et al. (2003) stated that growth heterogeneity is induced by a wide range of intrinsic and environmental factors, of which the relative influence is largely unknown but could be qualified as either inherent (i.e. having a strong genetic

\footnotetext{
a Corresponding author: david.benhaim@cnam.fr
}

component that is expressed to a varying degree according to the environmental conditions) or imposed (i.e. requiring specific biotic or abiotic conditions to be manifested). Among the biotic factors, social interaction has been identified as a major cause of individual variation in growth (Jobling et al. 1993; Cutts et al. 1998) if it leads to feeding hierarchies that decrease growth of low ranked fish (Koebele 1985). It is also well known that size-related dominance determines aggressive behaviour, feeding and growth performances in fish (Abbot and Dill 1989). Some mechanisms have been proposed to explain how such hierarchies could influence growth, e.g., physiological stress (Jobling 1985; Abbot and Dill 1989; Huntingford et al. 1993; Griffiths and Armstrong, 2002), disproportional food acquisition (Koebele 1985 ; Grant 1997), activity differences (Adams et al. 1998; Sloman and Armstrong 2002), and cost of dominance (Yamagishi et al. 1974; Rubenstein 1981).

In commercial fish farming, size grading is routinely carried out to ease feeding and harvesting operations (Lee 1988; Baardvik and Jobling 1990), and to avoid reduced survival via cannibalism in piscivorous species (Goldan et al. 1997). 
This procedure is based on the assumption that grading disrupts the development of social hierarchies, and allows the smaller fish to grow better in the absence of large dominant competitors (Strand and Øiestad 1997; Liao and Chang 2002). Some experiments supported the usefulness of grading procedures based on asymmetric competition (abalone, Haliotis tuberculata, Mgaya and Mercer 1995), while others reported either lower growth rates in graded fish (cod, Gadus morhua (Lambert and Dutil 2001) or no biomass gain: Arctic charr, Salvelinus alpinus (Wallace and Kolbeinshavn 1988; Baardvik and Jobling 1990); Atlantic salmon, Salmo salar (Gunnes 1976); eel, Anguilla anguilla (Kamstra 1993); Dover sole, Solea solea L. (Overton et al. 2010). In some species, destruction of size hierarchies does improve the growth of the small fish but the growth of the large fish could be adversely affected by the stronger agonistic interaction and intraspecific aggression occurring among the graded large individuals (Baardvik and Jobling 1990; Sunde et al. 1998; Stefánsson et al. 2000). Furthermore, size grading is in itself a stressful procedure for fish (Pickering 1981) and is labour-intensive, with risks of handling damage, disease outbreak, and growth reduction (Sunde et al. 1998). This further suggests that a better understanding of size variation mechanisms would be of high interest, and that efficient feeding modes and age-for-size grading methods could be better designed (Jørgensen and Jobling 1990; Benhaïm et al. 2003).

Study of feeding behaviour may contribute to a better understanding of size variation mechanisms. Feeding is a complex behaviour encompassing several behavioural responses associated with eating, including feeding modes and habits, mechanisms of food detection, feeding frequency, food preferences (Volkoff and Peter 2006), and foraging strategies (Benhaïm et al. 2003). Self-feeders are particularly useful for the study of feeding behaviour in fish (Boujard et al. 1992) and, when coupled with a PIT tag detection antenna, have contributed to a better understanding of individual behaviour within fish groups (Alanärä and Brännäs 1993, 1996; Brännäs and Alanärä 1993; Covès et al. 1998; Rubio et al. 2004; Covès et al. 2006). This combination of techniques was successfully used in European sea bass, a commercially important species in the Mediterranean (Covès et al. 1998; Covès et al. 2006; Di-Poï et al. 2007; Millot et al. 2008, 2009). Several authors have shown that, within a group of 50 juvenile sea bass, only a few individuals defined as high-triggering fish were responsible for the majority of food demands in the group, whereas the rest of the population exhibited the defined low- or zerotriggering activity (Covès et al. 2006; Di-Poï et al. 2007; Millot et al. 2008, 2009; Millot and Bégout 2009). Lastly, self-feeding systems are also very promising for fish farming because they can improve growth and feed conversion ratios (Azzaydi et al. 1998), they are an attractive alternative to either hand-feeding or automated feeding systems due to their low labour costs (Aloisi 1994), and offer a response to the new concerns about animal welfare, even though their commercial development has been rather limited.

Surprisingly, size-grading effects have never been studied under self-feeding conditions. The aim of the present work was, therefore, to analyse the influence of a size- grading protocol on feed demand behaviour, and social structure (in terms of individual triggering activity) in sea bass. In order to mimic grading procedures used in common fish husbandry, the approach consisted of a comparison of two groups of juveniles characterized by similar mean weight but contrasting coefficient of variation on weight $\left(C V_{\mathrm{w}}=10\right.$ vs. $\left.20 \%\right)$ and initial social structure (disrupted vs. non disrupted) while held under self-feeding conditions. Growth performance and blood physiological variables were measured to complete the characterisation.

\section{Materials and methods}

\subsection{Fish}

Sea bass used in this experiment were hatched and grown in a private farm, Aquanord (France), and were never sizegraded from $2 \mathrm{~g}$ until the beginning of the present experiment. At the mean weight of $40 \mathrm{~g}, 600$ fish were transferred to the Ifremer experimental station located in L'Houmeau (France). After a two-week acclimation period, each fish was PIT-tagged by inserting a tag horizontally just behind the head to prevent any change of position after implantation. Fish were then weighed (to the nearest $\mathrm{mg}$ ), and measured for total length (to the nearest $\mathrm{mm}$ ). At the beginning of the experiment, fish of the experimental population had an average initial body weight $\left(B W_{\mathrm{i}}\right)$ of $40.3 \pm 8.9 \mathrm{~g}$ and $C V_{\mathrm{w}}=22.2 \%(N=600)$. They were randomly distributed between 6 tanks (100 fish per tank) held in a single experimental room, as described below.

\subsection{Experimental set-up}

The experiment was carried out in six 400 L tanks supplied with filtered seawater in a recirculating system (flow rate: $4 \mathrm{~m}^{3} \mathrm{~h}^{-1}$ in each tank, and water renewal: $10 \%$ per day). The mean water temperature, oxygen concentration, and salinity were $21.0 \pm 0.9^{\circ} \mathrm{C}, 7.5 \pm 1.5 \mathrm{mg} \mathrm{L}^{-1}$, and $23.4 \pm 1.3 \mathrm{~g} \mathrm{~L}^{-1}$, respectively, throughout the experiment. Tanks were surrounded by black curtains to reduce any visual disturbance to the fish, and lit by individual $120 \mathrm{~W}$ lamps located about $90 \mathrm{~cm}$ above the water surface. Light regime was 16:8 LD (light onset at 06:00 h, UT $+1 \mathrm{~h}$ ) with twilight transition periods of $30 \mathrm{~min}$ (06:00 to 06:30 and 22:00 to 22:30 h). Fish were fed a commercial sea bass diet (Neo Start 3 Le Gouessant, France; $47 \%$ crude protein, $18 \%$ lipid according to the manufacturer; $3.2 \mathrm{~mm}$ ). Each tank was provided with a self-feeder. The device that operates these feeders is made up of a screened-type sensor (a metal rod protected in a PVC cylinder surrounded by the PIT tag detection antenna; Covès et al. 2006), and a control box. After each actuation, fish were rewarded with pellets. The feed dispensers were regulated to distribute between $0.8 \mathrm{~g} \mathrm{~kg}^{-1}$ and $0.6 \mathrm{~g} \mathrm{~kg}^{-1}$ of fish at the beginning and end of the experiment, respectively. The reward level was a compromise between minimizing wastage, and optimizing feed allocation to the group. Such a set up allowed us to monitor two variables of interest on a daily basis: the individual feed demand behaviour, and the group (i.e. tank) apparent feed consumption (food quantity dispensed minus waste counted on the bottom of the tank and in the sediment trap). Triggering activity was 
recorded continuously for 82 days, and only stopped $48 \mathrm{~h}$ before and during fish handling (when no recordings were made and the fish were fasted; 10 days off in total). Fish were placed under self-feeding conditions from the very first day (D1) of the experiment, food access was possible all day $(24 \mathrm{~h})$ even during tank cleaning, and waste counting occurred from 10:00 to 11:00 h (UT $+1 \mathrm{~h})$.

The experiment lasted 82 days in total, during which the fish were weighed, and measured (anesthetized with clove oil at $40 \mathrm{ppm}$ ) at fortnightly intervals: days 13 (D13), 27 (D27), 41 (D41), 54 (D54), 69 (D69), and 82 (D82).

\subsection{Experimental periods}

The experiment was run from 7 May to 28 July 2009, structured into three periods where the same set of variables (selffeeding behaviour, social structure, and growth performances) were measured on graded, and non-graded fish:

- The first 27-day period $(P 1)$ allowed variable estimation in non-graded fish. It included the self-feeder learning process, i.e., the time taken by fish in each tank to learn selffeeder triggering ( 6 tanks of 100 fish; $B W=40.2 \pm 8.9 \mathrm{~g}$ ).

- The second 27-day period $(P 2)$ allowed variable estimation in graded fish. The grading was carried out at D27 by creating two groups of similar mean weight but either a high or low $C V_{\mathrm{w}}\left(T_{\text {high }}: C V_{\mathrm{w}} \sim 20 \%, 3\right.$ tanks of 60 fish; $T_{\text {low }}$ : $C V_{\mathrm{w}} \sim 10 \%, 3$ tanks of 60 fish).

- The third 27-day period ( $P 3$ ) was added to $P 2$, allowing the variable estimation in graded vs. non graded fish over a 54-day period $(P 2+P 3)$.

$C V_{\mathrm{w}}$ was calculated as: $100 S D \times B W^{-1}$, where $S D$ and $B W$ are the standard deviation and mean body weight respectively. To make the $T_{\text {high }}$ groups, fish from both extremes of the weight distribution were eliminated in each of three randomlyselected tanks; grading was done within tanks in order to maintain the social structure previously established during $P 1$. All other weight classes were retained, i.e., from 21.1 to $65.1 \mathrm{~g}$. To make the $T_{\text {low }}$ groups, fish from all three remaining tanks were pooled in a $2 \mathrm{~m}^{3}$ tank supplied with pure oxygen, and hand-graded to select fish belonging to a weight class ranging between 33.7 and $49.7 \mathrm{~g}$, thereby composing groups with a disrupted social structure compared with $P 1$. Handling stress was identical for each fish since they were all weighed, and measured before being placed in their new tank. These procedures created the following group characteristics:

- $T_{\text {low }}$ groups: $B W=41.9 \mathrm{~g}, C V_{\mathrm{w}}=9.5 \%$ in Tank $1 ; B W=$ $41.7 \mathrm{~g}, C V_{\mathrm{w}}=9.4 \%$ in Tank $2 ; B W=41.7 \mathrm{~g}, C V_{\mathrm{w}}=9.4 \%$ in Tank 3

- $T_{\text {high }}$ groups: $B W=38.1 \mathrm{~g}, C V_{\mathrm{w}}=20.4 \%$ in Tank 4; $B W=41.1 \mathrm{~g}, C V_{\mathrm{w}}=22.5 \%$ in Tank $5 ; B W=38.6 \mathrm{~g}$, $C V_{\mathrm{w}}=22.6 \%$ in Tank 6 .

\subsection{Measured and calculated variables}

The variables chosen to evaluate rearing performances, and feeding behaviour within periods were the following (most were normalized against fish biomass to account for inter-tank differences): body weight, $B W(\mathrm{~g})$; total body length, $B L(\mathrm{~cm})$; specific growth rate (\% body weight per day), $S G R=100$ (ln $\left.B W_{\mathrm{f}}-\ln B W_{\mathrm{i}}\right) / t$, whith $B W_{\mathrm{f}}$ and $B W_{\mathrm{i}}$ being the final and initial body weight $(\mathrm{g})$ respectively, and $t$ the total number of days; Fulton condition factor $\left(K=100 B W \times B L^{-3}\right)$; Feed demand, $F D$ ( $\mathrm{g} \mathrm{kg}^{-1}$ of fish biomass); Food wastage, $F W(\mathrm{~g})$; Feed conversion ratio ( $F C R=F D /$ biomass gain $)$; Feeding rhythms calculated by taking into account the feeding demand per hour;

Social structure was established according to fish individual triggering level, classifying them into 3 categories according to their proportional contribution to total number of trigger actuations within a group: high-triggering (HT) (>15\% actuations), low-triggering (LT) $(<15 \%)$, and zero-triggering (ZT) $(<2 \%)$ individuals (based on Covès et al. 2006).

Physiological status of graded and non-graded fish was evaluated from blood samples $(0.1 \mathrm{ml}$ taken from the caudal vessel with a 1-ml heparinized syringe) of 4 anesthetized fish randomly taken from each tank at D82. Blood was immediately analysed using an I-Stat ${ }^{\circledR}$ Portable Clinical Analyzer (Abbott; cartridges CG8+; Heska Corporation, Fort Collins CO, USA; Harrenstien et al. 2005) to evaluate the 13 following variables:

$\mathrm{pH}$; carbon dioxide partial pressure, $\mathrm{pCO}_{2}(\mathrm{~mm} \mathrm{Hg})$; oxygen partial pressure, $\mathrm{pO}_{2}(\mathrm{~mm} \mathrm{Hg})$; base excess, $\mathrm{BE}(\mathrm{mmol}$ $\left.\mathrm{L}^{-1}\right)$; bicarbonate, $\mathrm{HCO}_{3}^{-}\left(\mathrm{mmol} \mathrm{L}^{-1}\right)$; total carbon dioxide, total $\mathrm{CO}_{2}\left(\mathrm{mmol} \mathrm{L}{ }^{-1}\right)$; oxygen saturation, $\mathrm{O}_{2}$ saturation (\%); potassium ion, $\mathrm{K}^{+}\left(\mathrm{mmol} \mathrm{L}^{-1}\right)$; sodium ion, $\mathrm{Na}^{+}\left(\mathrm{mmol} \mathrm{L}^{-1}\right)$; ionized calcium, iCa $\left(\mathrm{mmol} \mathrm{L}^{-1}\right)$; plasma glucose, Glu (mg $\left.\mathrm{dl}^{-1}\right)$; hematocrit, Hct (\% packed cell volume PCV), and haemoglobin, $\mathrm{Hb}\left(\mathrm{mmol} \mathrm{L}^{-1}\right)$.

\subsection{Statistical analyses}

All variables were compared using parametric analysis of variances (ANOVA) after verification of distribution normality, and homoscedasticity (Dagnélie 1975). When data did not fulfil these requirements, non parametric Kruskall-Wallis tests were used. Significant ANOVA were followed by a posthoc multiple comparison test (Newman-Keuls) and significant Kruskall-Wallis tests by rank-based multiple comparisons (Zar 1984). All statistical analyses were conducted using Statistica 8 (Statsoft, USA) with the significant threshold $p<0.05$ for all tests.

To assess for differences between tanks during $P 1$, all rearing performances were compared using a two-way ANOVA with Date (three dates corresponding to 5 biometry measurement dates) and Tank as fixed factors; $F D, F W$, and $F C R$ during $P 1$ were compared using a two-way analysis of the variance with Date (two dates corresponding to two biometry dates) and Tank as fixed factors.

To assess the influence of size grading, mean $F D, F W$, and $F C R$ during $P 1$ and $P 2$ were compared using a two-way ANOVA with Period as a fixed factor, and Tank as a random factor.

To assess for differences between $T_{\text {low }}$ and $T_{\text {high }}$ groups during $P 2$ and $P 3$, all rearing performance variables were compared using a 3-way ANOVA with Treatment ( $T_{\text {low }}$ vs. $T_{\text {high }}$ ), 
and Date (5 dates corresponding to 5 biometry dates) as fixed factors, and the Tank as a random factor nested to Treatment.

Data on feeding demand per hour from each treatment ( $T_{\text {low }}$ and $T_{\text {high }}$ ) were submitted to Cosinor analysis to test for the existence of statistically significant daily rhythms. Cosinor analysis is based on least squares approximation of time series data with a cosine function of known period of the type $Y=$ Mesor + Amplitude $\cos ((2 \pi$ ( $t$-Acrophase $) /$ Period $)$, where Mesor is the time series mean; amplitude is a measure of the amount of temporal variability explained by the rhythm; pe$\operatorname{riod}(t)$ is the cycle length of the rhythm, i.e., $24 \mathrm{~h}$ for circadian rhythms; and acrophase is the time of the peak value relative to the designated time scale. Cosinor analysis also provided a statistical value for a null hypothesis of zero amplitude. Therefore, if this null hypothesis was rejected for a statistical significance of $p<0.05$, the amplitude could be considered as differing from 0 , thereby constituting evidence for the existence of a statistically significant rhythm of the period considered. In order to statistically compare $T_{\text {low }}$ and $T_{\text {high }}$ feeding rhythms, ANOVA was used, with Treatment and Hour as fixed factors and Tank as a random factor nested to Treatment.

For physiological blood parameters, a 2-way ANOVA was used, with Treatment as a fixed factor and Tank as a random factor nested to Treatment. Pearson coefficients $(R s)$ were used to test for associations between initial and final weight between biometry dates (D27-D41, D41-D54, D54-D69, D69-D82) in each tank.

To assess for differences between triggering fish categories (HT, LT and ZT), $B W, B L$, and $S G R$ were compared between biometry dates and tanks using Kruskal-Wallis tests, while percentages of triggering fish were compared using MannWhitney tests.

\section{Results}

During the experiment, mortality rate was $2.2 \pm 3.4 \%$. On average (all tanks), biomass was $4025 \pm 108 \mathrm{~g}$ (density $10.1 \pm$ $\left.0.3 \mathrm{~kg} \mathrm{~m}^{-3}\right)$ at the beginning of $P 1$ and $4380 \pm 517 \mathrm{~g}(10.9 \pm$ $\left.1.3 \mathrm{~kg} \mathrm{~m}^{-3}\right)$ at the end; $2822 \pm 119 \mathrm{~g}\left(7.0 \pm 0.3 \mathrm{~kg} \mathrm{~m}^{-3}\right)$ at the beginning of $P 2$ and $3886 \pm 136 \mathrm{~g}\left(9.7 \pm 0.3 \mathrm{~kg} \mathrm{~m}^{-3}\right)$ at the end; and $3886 \pm 136 \mathrm{~g}\left(9.7 \pm 0.3 \mathrm{~kg} \mathrm{~m}^{-3}\right)$ at the beginning of $P 3$ and $5144 \pm 254 \mathrm{~g}\left(12.9 \pm 0.6 \mathrm{~kg} \mathrm{~m}^{-3}\right)$ at the end.

\subsection{Differences between tanks during $P 1$}

$B W, B L$, and $\mathrm{K}$ increased more from D13 $(41.1 \pm 8.9 \mathrm{~g}$, $15.8 \pm 1.1 \mathrm{~cm}, 1.0 \pm 0.1 \%)$ to D26 $(47.7 \pm 9.9 \mathrm{~g}, 16.4 \pm 1.1 \mathrm{~cm}$, $1.1 \pm 0.1 \%)$ than they had from D1 $(40.2 \pm 8.9 \mathrm{~g}, 15.5 \pm$ $1.1 \mathrm{~cm}, 1.0 \pm 0.1 \%)$ to D13. There were significant interactions between Date and Tank in all cases $\left(F_{(10,1674)}=111.4\right.$, $p<0.001 ; F_{(10,1674)}=2.8, p<0.001$ and $F_{(10,1674)}=29.6$, $p<0.001$ respectively) with tanks 1 and 6 being significantly higher at D26 than all other tanks at any date $(p<0.05$ in all cases). $S G R$ strongly increased from D1-D13 $(0.13 \pm 0.35)$ to D13-D26 (1.00 \pm 0.26$)$ with a significant interaction between Date and Tank $\left(F_{(5,1088)}=14.2, p<0.001\right)$. Newman-Keuls tests showed significant differences for each pairwise comparison $(p<0.05)$.
$F D$ increased from D13 $\left(10.9 \pm 11.1 \mathrm{~g} \mathrm{~kg}^{-1}\right)$ to D26 $\left(16.7 \pm 9.7 \mathrm{~g} \mathrm{~kg}^{-1}\right)$ and there were significant Date and Tank effects $\left(F_{(1,107)}=13.5, p<0.001\right.$ and $F_{(5,107)}=3.2, p<$ $0.001)$ respectively) values being higher in tank 4 than in tank $5(p<0.05)$. FCR decreased from D13 $(1.0 \pm 4.1)$ to D26 $(0.8 \pm 2.8)$ and there was a significant interaction between Tank and Date $\left(F_{(5,107)}=2.9, p<0.05\right)$ with Tank 3 at D13 being higher than all other tanks at any date $(p<0.05$ for each pairwise comparison). $F W$ was negligible during $P 1$ (lower than $1 \mathrm{~g}$ per day on average).

\subsection{Influence of size grading protocol}

FD increased by $24 \%$ from $P 1\left(14.3 \pm 6.1 \mathrm{~g} \mathrm{~kg}^{-1} \mathrm{day}^{-1}\right)$ to $P 2\left(18.7 \pm 10.7 \mathrm{~g} \mathrm{~kg}^{-1} \mathrm{day}^{-1}\right)\left(F_{(1,180)}=10.7, p=0.02\right)$, and neither a Tank effect nor an interaction between Tank and Period were observed. FW was $0.2 \pm 0.6 \mathrm{~g}$ during $P 1$ and $4.5 \pm$ $4.9 \mathrm{~g}$ during $P 2$. Differences could not be tested because an interaction existed between Period and Tank $\left(F_{(5,180)}=22.8\right.$, $p<0.001)$ due to one tank where the amount of uneaten food pellets collected daily increased after size grading (from $0.5 \pm$ 1.1 to $23.6 \pm 21.0 \mathrm{~g}$ ). In all other tanks, this amount remained very low (between 0-2 g per day) before and after size grading. Mean food conversion rate were $1.5 \pm 2.7$ and $1.5 \pm 0.5$ for $P 1$ and $P 2$ respectively but differences could not be tested for the same reason as above: an interaction between Tank and Period was observed $\left(F_{(5,180)}=2.7, p=0.02\right)$.

During $P 1$, percentages of fish observed in the ZT category were between 87 and $93 \%$ (Fig. $1 P 1$ ). These percentages decreased during $P 2$ in each tank except tank 2 (Fig. 1 $P 2)(Z=-2.9, p<0.05)$. At the same time, percentages of HT fish increased $(Z=-1.89, p=0.057)$, except in tank 6 : 9-11 vs. $15-17 \%$ in tank $1,12-14$ vs. $33-35 \%$ in tank $2,6-8$ vs. $9-11 \%$ in tank $4,6-8$ vs. $19-20 \%$ in tank 5 , for $P 1$ and $P 2$ respectively (Fig. 1), and percentages of LT fish increased $(Z=-2.9, p<0.05)$ in all tanks $(14.2 \pm 2.5$ vs. $31.5 \pm 8.0 \%)$.

\subsection{Comparison of $T_{\text {low }}$ and $T_{\text {high }}$ treatments during $P 2$ and $P 3$}

\subsubsection{Rearing performances}

The evolution of mean $B W, B L$ and $\mathrm{K}$ of all groups during $P 2+P 3$ is presented in Figure 2. There was no difference in growth performances between the $T_{\text {low }}$ and $T_{\text {high }}$ groups i.e., no Treatment effect was recorded for any dependant variable (Table 1). This was confirmed by the stability of the $C V_{\mathrm{w}}$ (Fig. 2D). In $T_{\text {low }}$ groups, $C V_{\mathrm{w}}$ even tended to slightly decrease from the beginning to the end of the experiment (from $20.9 \pm$ $1.3 \%$ to $18.8 \pm 1.0 \%$ ) whereas it slightly increased in $T_{\text {high }}$ groups (from $9.9 \pm 0.2 \%$ to $10.8 \pm 1.0 \%$ ). The $S G R$ decreased irregularly during the course of the experiment (Fig. 2E), being similar at D26 and D41, lower at D54, higher again at D69, and reaching the lowest value at D82 (Table 1). SGR was not exactly the same among tanks, as tanks 1 and 6 showed a different evolution over the experiment. Tank $1 S G R$ increased from D41 to D54 (but was at the lowest level compared with the other tanks at D41), decreased between D54 and D69 and 

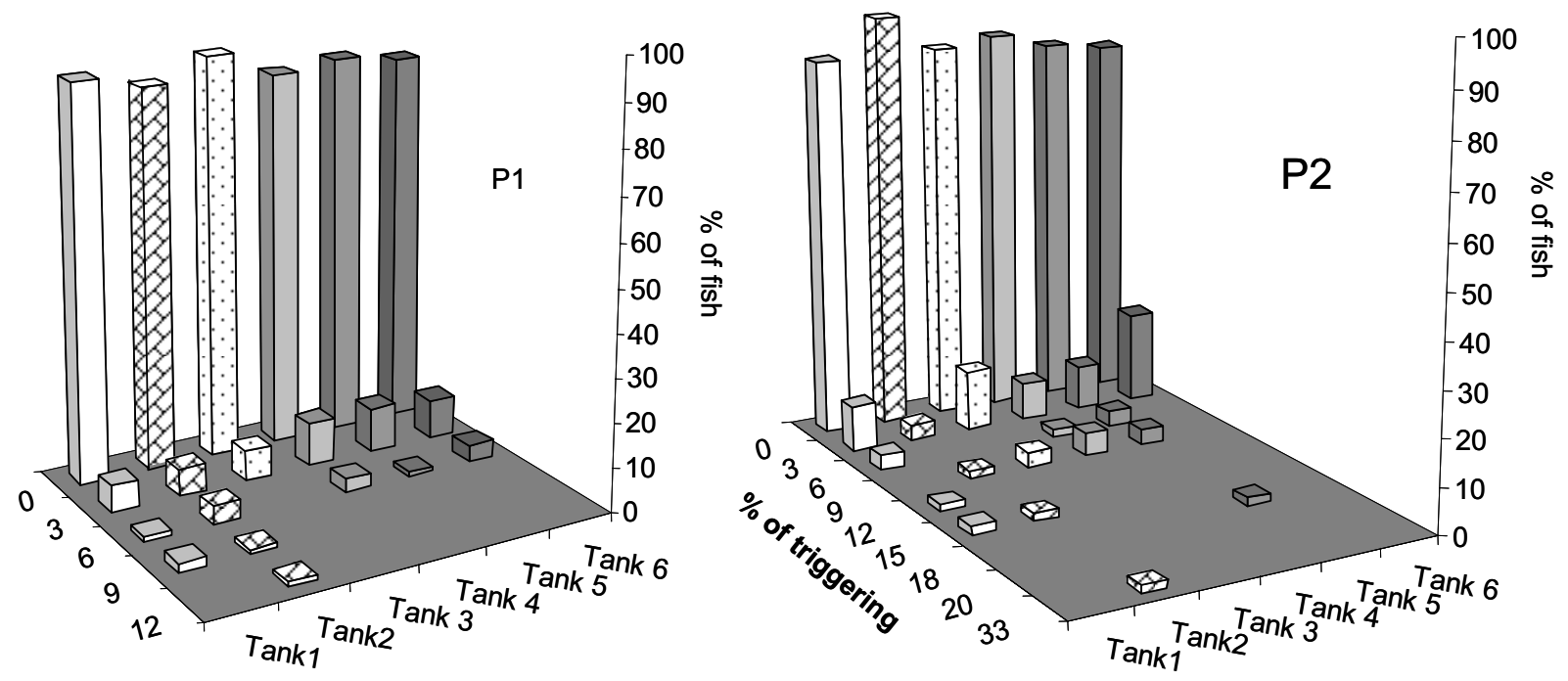

Fig. 1. Social structure measured by the percentage of triggering acts per individual before and after size grading. Percentages of fish are given in each triggering activity class: 0 refers to $0-2,3$ to $3-5$ etc. $P 1$ : before size grading (Day 1-Day 27). P2: after size grading (Day 28-Day 55). In $P 2, T_{\text {low }}$ : tanks 1,2 and $3 ; T_{\text {high }}$ : tanks 4,5 and 6.

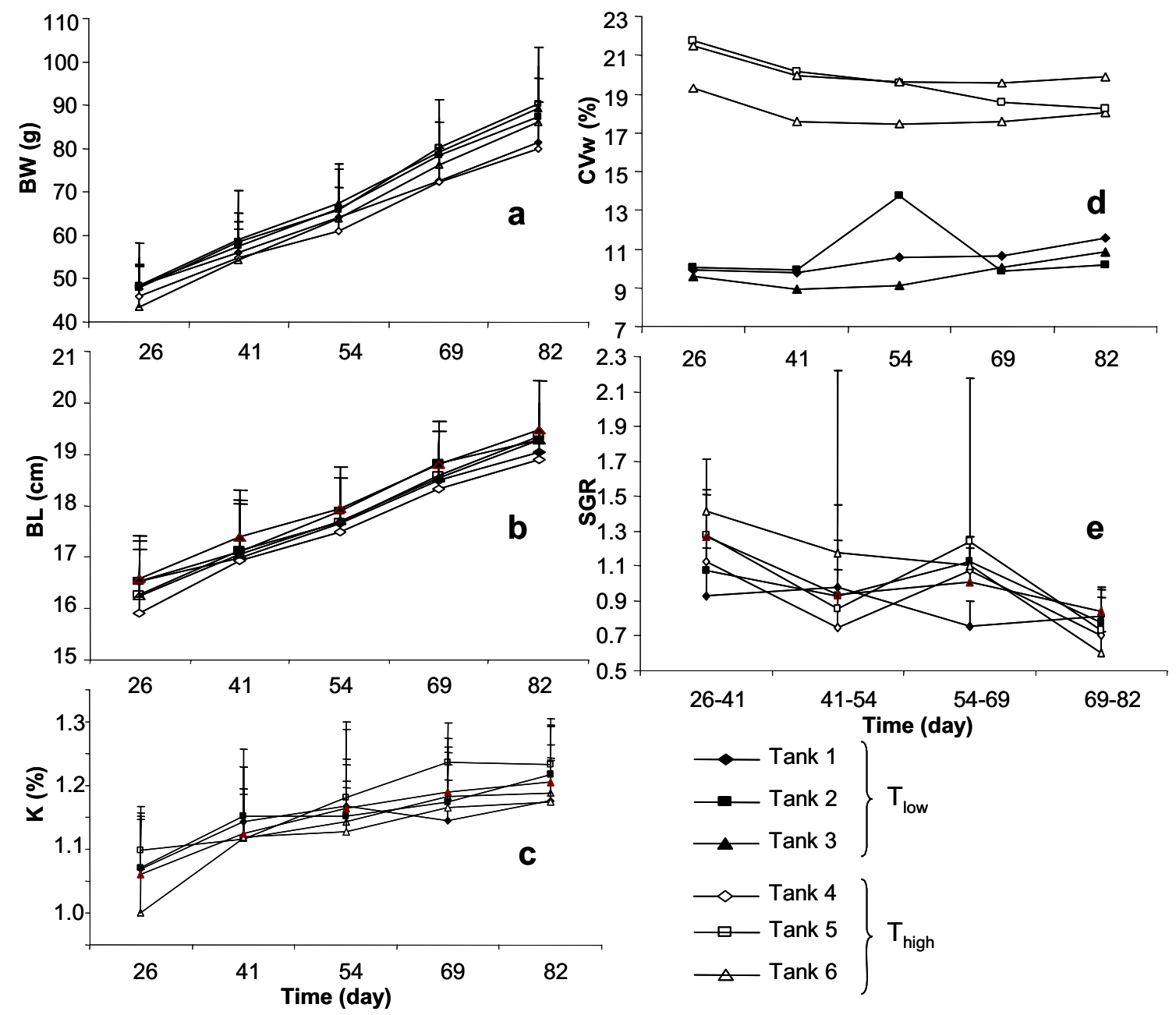

Fig. 2. Growth performances (mean $\pm S D$ ) of two groups of sea bass graded for high $\left(T_{\text {high }}\right)$ and low $\left(T_{\text {low }}\right)$ coefficient of variation of weight. $T_{\text {low }}: C V_{\mathrm{w}} \sim 10 \%$, and $T_{\text {high }}: C V_{\mathrm{w}} \sim 20 \%$. $B W$ : body weight; $B L$ : total body length; K: Fulton index; $C V_{\mathrm{w}}$ : coefficient of variation of body weight. $S G R$ : specific growth rate; $S D$ : standard deviation. 
Table 1. Results of ANOVA and Newman-Keuls tests used to analyse the mean differences between treatments $\left(T_{\text {low }}: C V \sim 10 \%:\right.$ low $C V$ of weight; $T_{\text {high }}: C V \sim 20 \%$ : high $C V$ of weight) (fixed factor), Date (fixed factor) and Tanks (random factor nested to Treatment). $B W$ : Body weight; $B L$ : Total body length; SGR: specific growth rate. D1: Day 26; D2: Day 41; D3: Day 54; D4: Day 69; D5: Day 82. Significance threshold was $p<0.05$.

\begin{tabular}{lccclc}
\hline & Source & $d f$ & $F$ & $p$ & Newman-Keuls \\
\hline \multirow{3}{*}{$B W(\mathrm{~g})$} & Treatment & $1 \& 1771$ & 0.5 & 0.519 & \\
& Tank (treatment) & $4 \& 1771$ & 31.3 & $<0.001$ & \\
& Date & $4 \& 1771$ & 782.6 & $<0.001$ & D5 $>$ D4 $>$ D3 $>$ D2 $>$ D1 \\
\hline \multirow{3}{*}{$B L(\mathrm{~cm})$} & Treatment & $1 \& 1771$ & 1.7 & 0.268 & \\
& Tank (treatment) & $4 \& 1771$ & 0.7 & 0.562 & \\
& Date & $4 \& 1771$ & 115.9 & $<0.001$ & D5 $>$ D4 $>$ D3 $>$ D2 $>$ D1 \\
\hline \multirow{2}{*}{$S G R$} & Treatment & $1 \& 1771$ & 0.1 & 0.805 & \\
& Tank (treatment) & $4 \& 1771$ & 5.1 & $<0.001$ & \\
& Date & $4 \& 1771$ & 65.3 & $<0.001$ & D5 $<$ D1 $=$ D2 $<$ D4 $<$ D3 \\
\hline
\end{tabular}

Table 2. Spearman coefficients $(r)$ between initial and final body weight in $T_{\text {low }}(C V \sim 10 \%$ : low $C V$ of weight $)$ and $T_{\text {high }}(C V \sim 20 \%$ : high $C V$ of weight). $T_{\text {low }}$ (Tanks 1,2 and 3) and $T_{\text {high }}$ (Tanks 4, 5 and $6)$. $* * p<0.01, * * * p<0.001$. Results of rank-based multiple comparisons between tanks are shown with the letters a and $b$. When two tanks have different letters they significantly differ at $p<0.05$.

\begin{tabular}{lcccccccc}
\hline & \multicolumn{2}{c}{ D41 } & \multicolumn{2}{c}{ D54 } & \multicolumn{2}{c}{ D68 } & \multicolumn{2}{c}{ D82 } \\
\hline Tank & $r$ & $p$ & $r$ & $p$ & $r$ & $p$ & $r$ & $p$ \\
\hline 1 & 0.92 & $* * *$ & 0.94 & $* * *$ & 0.96 & $* *$ & 0.95 & $* *$ \\
$2^{\mathrm{a}}$ & 0.85 & $* * *$ & 0.90 & $* * *$ & 0.92 & $* * *$ & 0.97 & $* *$ \\
3 & 0.88 & $* * *$ & 0.96 & $* *$ & 0.95 & $* *$ & 0.99 & $* *$ \\
4 & 0.96 & $* * *$ & 0.99 & $* *$ & 0.98 & $* *$ & 0.98 & $* *$ \\
$5^{\mathrm{b}}$ & 0.98 & $* *$ & 0.99 & $* *$ & 0.99 & $* *$ & 0.99 & $* *$ \\
6 & 0.97 & $* *$ & 0.98 & $* *$ & 0.98 & $* *$ & 0.99 & $* *$ \\
\hline
\end{tabular}

increased again till the end of the experiment. Tank 6 was the only one to show a regular decrease in $S G R$ from the beginning to the end of these periods. At D82, all tanks had reached similar $S G R$ values.

Spearman rank correlation coefficients for $B W$ calculated between two successive dates were close to 1 in both treatment groups and significant in all cases (Table 2). Nevertheless, observed tendencies were different between the $T_{\text {low }}$ and $T_{\text {high }}$ groups. In $T_{\text {high }}$ groups, coefficients remained very stable during the experiment, demonstrating a linear relationship at a value of 0.98 between initial and final body weight. In $T_{\text {low }}$ groups, Spearman rank correlation coefficient increased ( 0.85 to 0.98 in average) from the beginning to the end of the experimental period. There was a significant Tank effect $\left(H_{(5,23)}=13.7, p=0.017\right)$, with tank 2 having a higher coefficient than tank $5(p=0.04)$.

\subsubsection{Feeding behaviour}

FD and FW were similar in $T_{\text {low }}\left(18.3 \pm 0.7 \mathrm{~g} \mathrm{~kg}^{-1} \mathrm{day}^{-1}\right.$ and $14.0 \pm 24.0 \mathrm{~g})$ and $T_{\text {high }}$ groups $\left(17.6 \pm 4.5 \mathrm{~g} \mathrm{~kg}^{-1} \mathrm{day}^{-1}\right.$ and $0.9 \pm 1.3 \mathrm{~g}$ ) throughout the whole period but Tank (Treatment) effect was significant for both variables $\left(F_{(4,121)}=\right.$ $7.8, p<0.001$ and $\left.F_{(4,121)}=33.6, p<0.001\right)$. Indeed, $F W$ was
Table 3. Mean \pm SE. Cosinor values for feeding demand per hour $\left(F D, \mathrm{~g} \mathrm{~kg}^{-1}\right)$ in groups with high $\left(T_{\text {high }}\right)$ and low $\left(T_{\text {low }}\right)$ coefficient of variation in weight. $T_{\text {low }}: C V_{\mathrm{W}} \sim 10 \%$, and $T_{\text {high }}: C V_{\mathrm{W}} \sim 20 \%$. Mesor and amplitude are expressed in $\mathrm{g} \mathrm{kg}^{-1}$. The reference phase for the acrophase refers to the time of day and is expressed in hours (h:min).

\begin{tabular}{lcc}
\hline Feeding demand $(F D)$ & $T_{\text {low }}$ & $T_{\text {high }}$ \\
\hline Acrophase $(\mathrm{h}: \mathrm{min})$ & $8: 17 \pm 0: 27$ & $11: 34 \pm 0: 34$ \\
Amplitude $\left(\mathrm{g} \mathrm{kg}^{-1}\right)$ & $2.05 \pm 0.11$ & $1.40 \pm 0.10$ \\
Mesor $\left(\mathrm{g} \mathrm{kg}^{-1}\right)$ & $2.67 \pm 0.08$ & $2.01 \pm 0.07$ \\
$p$ & $* * *$ & $* * *$ \\
\hline
\end{tabular}

very low in all tanks $(0.6 \pm 1.6 \mathrm{~g})$ except tank $3(41.7 \pm 33.7 \mathrm{~g})$. Date effect was not significant for $F D$ or for $F W$. No difference in mean $F C R$ was evident between the two groups: $1.3 \pm 0.1$ to $2.4 \pm 0.3$ from the beginning to the end of the experiment for $T_{\text {low }}$, and $1.3 \pm 0.3$ to $1.9 \pm 0.4$ for $T_{\text {high }}$, but there were significant Date and Tank (Treatment) effects $\left(F_{(3,121)}=13.3 ; p<\right.$ 0.001 and $\left.F_{(4,121)}=3.7, p<0.01\right)$. The Tank (Treatment) effect came from tank 4, where $F C R$ was lower than in the other tanks $(1.09 \pm 0.27$ vs. $1.50 \pm 0.52)$. Newman-Keuls post- hoc tests showed that FCR increased with time $(p<0.01$ for each pairwise comparison).

\subsubsection{Feeding rhythm}

A highly significant daily rhythm in $F D$ was observed in both treatments, with the acrophase in the morning (Table 3 ). Mesor and Amplitude were higher in $T_{\text {low }}$ than $T_{\text {high }}$ groups.

Feeding demand varied between a minimum of 1.2 and a maximum of $3.8 \mathrm{~g} \mathrm{~kg}^{-1}$ during $P 2+P 3$. Two main feeding activity peaks were observed at 06:00 and 11:00 h (Fig. 3). No difference could be observed in the mean overall demand of $T_{\text {low }}$ and $T_{\text {high }}$ groups but Hour effect was highly significant $\left(F_{(23,2100)}=9.1, p<0.001\right)$, with higher demands at 6:00 and 11:00 h compared to all other time slots $(p<0.01$ for each pairwise comparison). The number of demands observed during these two peaks did not differ, but Tank (Treatment) effect was significant $\left.F_{(4,2100)}=23.5, p<0.001\right)$. 


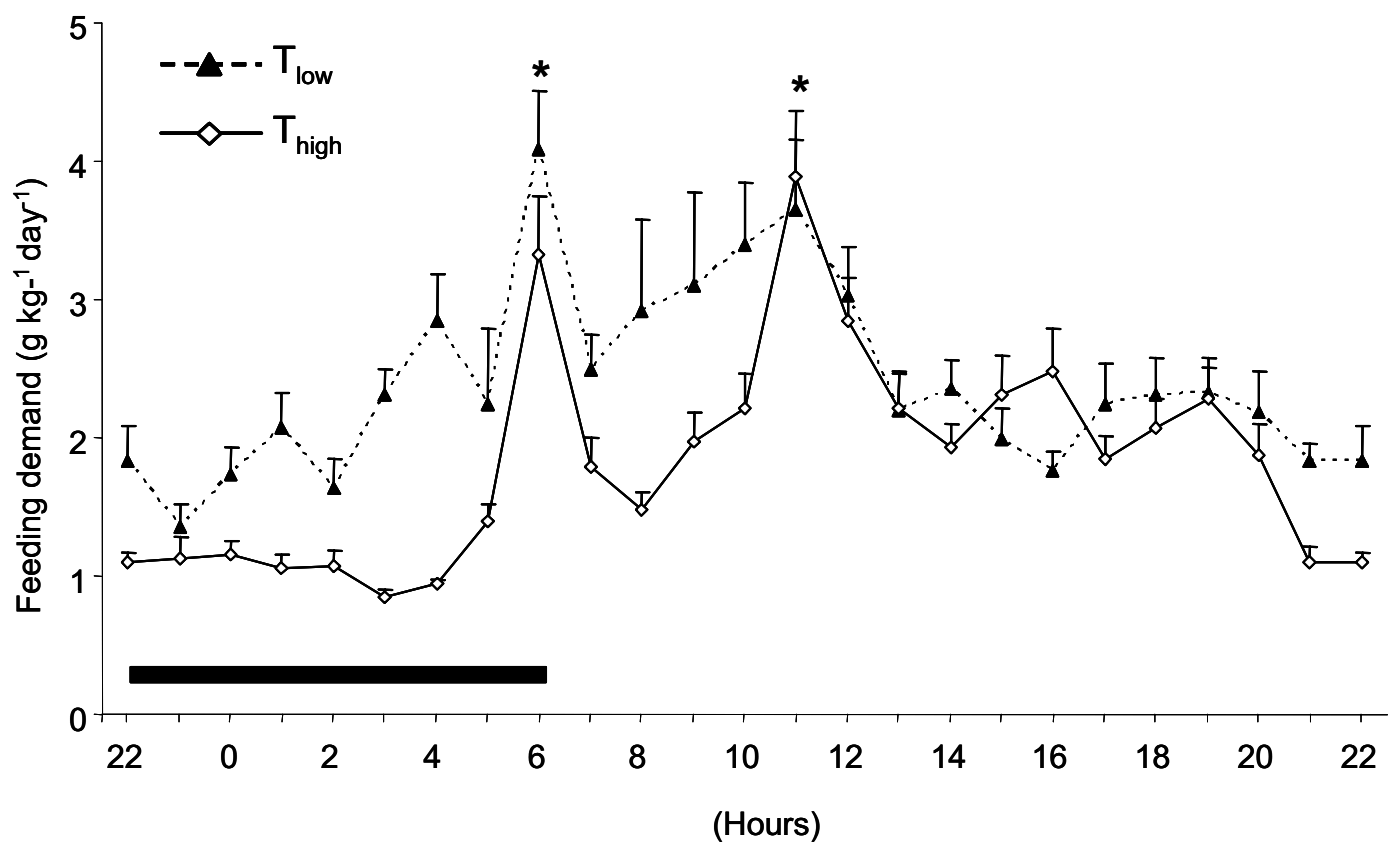

Fig. 3. Feeding rhythm difference (mean $\pm \mathrm{SE}$ ) between $T_{\text {low }}\left(C V \sim 10 \%\right.$ : low $C V$ of weight) and $T_{\text {high }}(C V \sim 20 \%$ : high $C V$ of weight). The black mark on the $X$-axis represents the night period. * indicates a significant feeding peak $(p<0.05)$.

Table 4. Percentage of fish in each tank for each feed-demand behaviour category; $S G R$ : specific growth rate (mean $\pm S D)$. Data are given for $P 1$ (Day 1-Day 27), $P 2$ (Day 28-Day 55) and $P 3$ (Day 56-Day 82),. $T_{\text {low }}$ (group with low coefficient of variation in weight, $C V \sim 10 \%$ ) are in tanks 1, 2 and 3; $T_{\text {high }}$ (group with high coefficient of variation in weight, $C V \sim 20 \%$ ) are in tanks 4,5 and 6 . High triggering: $>15 \%$ actuations, low-triggering: $<15 \%$ and zero-triggering: $<2 \%$.

\begin{tabular}{|c|c|c|c|c|c|c|c|c|c|c|c|c|c|c|c|c|c|}
\hline \multirow{3}{*}{ Tank } & \multicolumn{5}{|c|}{ High-triggering } & \multicolumn{6}{|c|}{ Low triggering } & \multicolumn{6}{|c|}{ Zero-triggering } \\
\hline & \multicolumn{3}{|c|}{$\%$} & \multicolumn{2}{|c|}{ SGR } & \multicolumn{3}{|c|}{$\%$} & \multicolumn{3}{|c|}{$S G R$} & \multicolumn{3}{|c|}{$\%$} & \multicolumn{3}{|c|}{ SGR } \\
\hline & $P 1$ & $P 2$ & $\begin{array}{ll}P 3 & P 1 \\
\end{array}$ & $P 2$ & $P 3$ & $P 1$ & $P 2$ & $P 3$ & $P 1$ & $P 2$ & $P 3$ & $P 1$ & $P 2$ & $P 3$ & $P 1$ & $P 2$ & $P 3$ \\
\hline 1 & 0.0 & 1.3 & 1.7 & $1.1 \pm 0.0$ & $0.9 \pm 0.0$ & 11.5 & 23.7 & 21.7 & $1.8 \pm 0.6$ & $1.1 \pm 0.4$ & $0.9 \pm 0.1$ & 88.5 & 75.0 & 76.7 & $1.5 \pm 0.9$ & $1.0 \pm 0.2$ & $0.8 \pm 0.2$ \\
\hline 2 & 0.0 & 3.0 & 1.7 & $0.9 \pm 0.0$ & $0.8 \pm 0.0$ & 15.6 & 25.3 & 13.6 & $1.5 \pm 1.2$ & $1.2 \pm 0.2$ & $0.8 \pm 0.1$ & 87.5 & 71.7 & 84.7 & $1.7 \pm 0.8$ & $1.0 \pm 1.5$ & $0.8 \pm 0.1$ \\
\hline 3 & 0.0 & 0.0 & 1.7 & & $0.8 \pm 0.0$ & 11.5 & 30.0 & 18.3 & $1.4 \pm 0.1$ & $0.9 \pm 0.1$ & $0.8 \pm 0.1$ & 91.7 & 70.0 & 80.0 & $1.4 \pm 1.0$ & $1.0 \pm 0.0$ & $0.8 \pm 0.1$ \\
\hline 4 & 0.0 & 0.0 & 0.0 & & & 17.7 & 36.7 & 27.1 & $1.5 \pm 0.3$ & $0.9 \pm 0.1$ & $0.7 \pm 0.1$ & 86.5 & 63.3 & 72.9 & $1.2 \pm 0.3$ & $0.7 \pm 0.2$ & $0.7 \pm 0.2$ \\
\hline 5 & 0.0 & 1.7 & 1.9 & $0.8 \pm 0.0$ & $0.7 \pm 0.0$ & 13.5 & 28.3 & 18.5 & $1.4 \pm 0.4$ & $0.9 \pm 0.1$ & $0.7 \pm 0.1$ & 88.5 & 70.0 & 79.6 & $1.4 \pm 0.4$ & $0.9 \pm 0.2$ & $0.7 \pm 0.1$ \\
\hline 6 & 0.0 & 0.0 & 0.0 & & & 15.6 & 45.0 & 22.0 & $0.5 \pm 1.1$ & $1.2 \pm 0.2$ & $0.8 \pm 0.1$ & 88.5 & 55.0 & 78.0 & $0.3 \pm 0.4$ & $1.3 \pm 0.3$ & $0.9 \pm 0.1$ \\
\hline
\end{tabular}

\subsubsection{Social structure}

The percentage of high, low or zero triggering fish is presented in Table 4. No HT fish were observed during $P 1$. This category appeared during $P 2$ in two of the three $T_{\text {low }}$ groups ( 1 and $3 \%$ ) and in one $T_{\text {high }}$ group (2\%). At the end of $P 3$, there were $2 \%$ of HT fish in all $T_{\text {low }}$ groups, and $2 \%$ in one tank out of the $T_{\text {high }}$ groups. In $T_{\text {low }}, 2$ fish were responsible for $28 \%$ of the triggering-activity in tank 1,1 fish for $32 \%$ in tank 2 , and 1 fish for $18 \%$ in tank 3 . In $T_{\text {high }}$ groups, none of the fish showed a triggering activity higher than $15 \%$ except in tank 5 (1 fish responsible for $19 \%$ of the triggering activity). In tank 4, five fish were responsible for $15 \%$ of the triggering activity; and in tank 6, 10 fish were responsible for $50 \%$ of the triggering activity. At the same time, 18 and $81 \%$ of LT and ZT fish were observed respectively in $T_{\text {low }}$ groups, vs. 23 and $77 \%$ in $T_{\text {high }}$ groups. None of these percentages were significantly different between $T_{\text {low }}$ and $T_{\text {high }}$ groups.
The growth performances of HT, LT and ZT fish (Table 4) were not significantly different. For all variables, Date effect was significant $(p<0.001$ in all cases): $B W$ $\left(H_{(4,1780)}=1203.0\right) ; B L\left(H_{(4,1780)}=1064.0\right) ; S G R\left(H_{(4,1758)}=\right.$ 546.0); $K\left(H_{(4,1780)}=430.4\right)$. The variability was higher between tanks than between social categories i.e. Tank effect was significant in all cases $(p<0.01): B W\left(H_{(5,1780)}=25.9\right)$; $B L\left(H_{(5,1780)}=21.1\right) ; S G R\left(H_{(5,1758)}=39.1\right) ; K\left(H_{(5,1780)}=\right.$ 64.5). SGR variability came from the HT category at $P 1$ (Table 4), SGR was indeed lower in tanks 1 and 2 compared to LT and ZT categories, but higher in tanks 5 and 3. Conversely, $S G R$ was similar in low and zero-triggering individuals.

\subsubsection{Fish physiology}

Blood plasma characteristics were similar in both $T_{\text {low }}$ and $T_{\text {high }}$ groups (Table 5). No Treatment effect was recorded for any variables and there was only a Tank effect for blood $\mathrm{pO}_{2}$. 
Table 5. Blood plasma parameters (mean $\pm S D)$ in in groups with high $\left(T_{\text {high }}\right)$ and low $\left(T_{\text {low }}\right)$ coefficient of variation in weight. $T_{\text {low }}: C V_{\mathrm{w}} \sim 10 \%$, and $T_{\text {high }}: C V_{\mathrm{w}} \sim 20 \%$ at the end of the experiment (Day 82). $d f$ : degree of freedom; * indicates a significant difference, threshold: $p<0.05$.

\begin{tabular}{|c|c|c|c|c|c|c|}
\hline & \multirow[t]{2}{*}{$T_{\text {low }}$} & \multirow[t]{2}{*}{$T_{\text {high }}$} & \multicolumn{2}{|c|}{$\begin{array}{l}\text { Treatment } \\
d f 1 \& 18\end{array}$} & \multicolumn{2}{|c|}{$\begin{array}{c}\text { Tank (treatment) } \\
d f 4 \& 18\end{array}$} \\
\hline & & & $F$ & $p$ & $F$ & $p$ \\
\hline $\mathrm{pH}$ & $7.2 \pm 0.1$ & $7.2 \pm 0.1$ & 0.0 & 0.9 & 1.0 & 0.4 \\
\hline $\mathrm{pCO}_{2}(\mathrm{~mm} \mathrm{Hg})$ & $32.2 \pm 7.1$ & $30.4 \pm 4.8$ & 0.0 & 0.8 & 0.4 & 0.8 \\
\hline $\mathrm{pO}_{2}(\mathrm{~mm} \mathrm{Hg})$ & $36.1 \pm 13.5$ & $37.8 \pm 10.9$ & 0.0 & 0.8 & 3.6 & $0.02 *$ \\
\hline $\mathrm{BE}\left(\mathrm{mmol} \mathrm{L}^{-1}\right)$ & $-14.6 \pm 2.6$ & $-16.2 \pm 2.0$ & 0.0 & 0.9 & 0.9 & 0.5 \\
\hline $\mathrm{HCO}_{3}^{-}(\mathrm{mmol} \mathrm{L}-1)$ & $13.2 \pm 2.3$ & $11.8 \pm 1.4$ & 0.0 & 0.9 & 0.8 & 0.5 \\
\hline Total $\mathrm{CO}_{2}\left(\mathrm{mmol} \mathrm{L}^{-1}\right)$ & $14.2 \pm 2.5$ & $12.6 \pm 1.6$ & 0.0 & 0.9 & 0.8 & 0.5 \\
\hline $\mathrm{O}_{2}$ saturation $(\%)$ & $57.4 \pm 21.1$ & $57.8 \pm 16.9$ & 0.0 & 0.9 & 0.7 & 0.6 \\
\hline $\mathrm{Na}^{+}\left(\mathrm{mmol} \mathrm{L}^{-1}\right)$ & $156.8 \pm 8.5$ & $159.6 \pm 10.2$ & 0.5 & 0.5 & 1.1 & 0.4 \\
\hline $\mathrm{K}^{+}\left(\mathrm{mmol} \mathrm{L}^{-1}\right)$ & $4.4 \pm 1.1$ & $4.3 \pm 0.7$ & 0.1 & 0.8 & 0.8 & 0.5 \\
\hline $\mathrm{iCa}\left(\mathrm{mmol} \mathrm{L}^{-1}\right)$ & $1.1 \pm 0.2$ & $1.2 \pm 0.4$ & 0.5 & 0.5 & 0.7 & 0.6 \\
\hline Glucose $\left(\mathrm{mg} \mathrm{dl}^{-1}\right)$ & $137.5 \pm 58.4$ & $129.5 \pm 32.8$ & 0.9 & 0.4 & 0.1 & 0.9 \\
\hline Hct (\% PCV) & $25.6 \pm 3.3$ & $26.6 \pm 6.4$ & 0.6 & 0.5 & 1.1 & 0.4 \\
\hline $\mathrm{Hb}\left(\mathrm{mmol} \mathrm{L}^{-1}\right)$ & $8.7 \pm 1.0$ & $9.0 \pm 2.2$ & 0.9 & 0.4 & 1.0 & 0.4 \\
\hline
\end{tabular}

This was due to tank 3 , where blood $\mathrm{pO}_{2}$ was lower compared with the other tanks, but only the difference with tank 1 was significant $(p<0.05)$.

\section{Discussion}

\subsection{Effects of the size grading protocol}

The main modification observed after applying the size grading protocol in this experiment was a $24 \%$ increase in feed demand. This difference cannot be totally explained by the grading protocol because the period preceding its application included a self feeder learning phase that was characterized by a low food demand but short, in accordance with the classic behaviour of this species (Rubio et al. 2003, 2004; Covès et al. 2006; Millot et al. 2008). This feed-demand increase was neither accompanied by food wastage nor feed conversion rate improvement, but showed similar and high day to day variations before and after size grading. This would confirm the need for a period of 22 days for the feed-demand to reach a suitable and stable level of feed reward for a group of European sea bass, as pointed out by Sánchez-Vázquez et al. (1994). The data also showed that the high variability of the food conversion rate between tanks at the beginning of the experiment was probably linked to the learning process, as this disappeared after size grading.

Triggering activity was also modified after size grading, with no fish displaying more than $12-14 \%$ of the total activity before size grading and conversely, almost none displaying less than $15 \%$ after size grading. According to the feeddemand behaviour classification previously described (Covès et al. 2006; Di-Poï et al. 2007, 2008; Millot et al. 2008), the present study therefore confirmed that within a group of 60 100 sea bass juveniles, only a few individuals were responsible for the majority of food demands, whereas the rest of the population exhibited low- or zero-triggering activity. It also showed, however, that high-triggering fish appeared only after size grading.

\subsection{The effects of a reduction in the body weight coefficient of variation}

The main result is the absence of impact on growth performances over the 54-days of the experiment, a phenomenon that has already been described in many species such as eel, turbot, Scophthalmus maximus, or Arctic charr (Kamstra 1993; Strand and Øiestad 1997; Sunde et al. 1998; Wallace and Kolbeinshavn 1988), although this is the first time this has been observed under self-feeding conditions. The growth was almost linear and mean $S G R$ values were slightly higher than values already published for sea bass of the same size reared under similar conditions (Muller-Feuga 1998; Millot et al. 2008).

Another interesting result was in the evolution of the body weight coefficients of variation, which increased in the $T_{\text {low }}$ groups while slightly decreasing in $T_{\text {high }}$ groups. This finding agrees with previous work done by Carmichael (1994) in channel catfish (Ictalurus punctatus), and by Sunde et al. (1998) in turbot. In the latter species, growth heterogeneity of graded groups was enhanced until it reached the value of the un-graded group. This has been called heterogeneity stabilisation or convergence. According to these authors, this phenomenon is always due to altered feeding behaviour or social hierarchical order. They hypothesized that fish competition was very high just after size grading, and decreased with time. In some species, size grading might lead to the destruction of size hierarchy, the growth of the large fish being adversely affected by the stronger agonistic interaction, and intraspecific aggression occur among the graded large individuals (Baardvik and Jobling 1990; Stefánsson et al. 2000; Sunde et al. 1998). In sea bass, no studies have reported a high level of aggression under self-feeding conditions, as the reward level after each trigger actuation usually optimizes feed allocation to the group. This was verified in the present study, where the regular growth evaluations and very low mortality rate showed no evidence that any injuries occurred over the course of the experiment. However, low aggression level 
does not mean absence of social interactions between fish. Indeed, in exploitation competition, there are no direct interactions between competitors; instead, one individual exploits and depletes a food patch before a second individual arrives (Ward et al. 2006). Recent work based on growth heterogeneity modelling in fish rearing systems rejected the hypothesis of competition decrease within time (Campéas 2009). According to this author, growth heterogeneity stability is not correlated with the stabilisation of social interactions (i.e., size had little or no effect on fight determinism), and $C V_{\mathrm{w}}$ stability is the result of the dominance pressure of large fish on small fish. Indeed, according to Drews (1993), dominance can be defined as the priority to food access, and small subordinates may have a reduced feeding rate in the presence of dominant fish (Abbot et al. 1985) despite surplus feed availability (Jobling and Wandsvik 1983; Øverli et al. 1998; Sloman and Armstrong 2002). In our study, this idea is supported by the fact that correlations between initial and final weights tended to be lower in $T_{\text {low }}$ groups, but at the end of experiment, when $C V_{\mathrm{w}}$ increased, correlations reached the same values as those of the $T_{\text {high }}$ groups. Indeed, Campéas (2009) showed that this tendency was related to a modification of fish rank (weight rank between the beginning and the end of the studied period) in low $C V_{\mathrm{w}}$ groups.

Growth heterogeneity was frequently shown to be accompanied by food wastage (McCarthy et al. 1992; Jobling and Baardvick 1994; McDonald et al. 1996), but in our trial neither feed-demand nor feed wastage were different between the high and low $C V_{\mathrm{w}}$ groups. In both cases, all the food delivered was ingested and, since all fish grew positively, it is very likely that they all had access to food.

Feeding rhythms were identical in both treatments, with two main peaks at 06:00 and 11:00 h confirming that sea bass given free access to the self-feeder have a predominantly diurnal feeding pattern. Nevertheless, the greatest activity was not concentrated at the end of the day, as has been described in previous work (Azzaydi et al. 1999). Such morning activity has already been observed for this species under similar conditions (Millot 2008; Millot and Bégout 2009), but varying patterns of feeding rhythms have also been reported by several authors (Anthouard et al. 1993; Sánchez-Vázquez et al. 1994, 1995, 1998; Bégout-Anras 1995; Boujard et al. 1996).

Over $P 2$ and $P 3$, the social structure was similar in low and high $C V_{\mathrm{w}}$ groups, and in line with that described by several authors for the species (Covès et al. 2006; Di-Poï et al. 2007; Millot et al. 2008). In both treatments, only two or three fish were responsible for about $35 \%$ of the triggering activity and in most cases, there was only one high-triggering fish. However, at the end of $P 3$, there were HT fish in all of the $T_{\text {low }}$ groups, but in only one tank of the $T_{\text {high }}$ groups. The remainder of the population was divided into two groups: about $20 \%$ of LT fish and $78 \%$ of ZT fish. Size structure is well known to play an important role in social interactions (Abbot and Dill 1989; Dou et al. 2004), and relative size is the most determinant factor in fighting ability during aggressive behaviour, as well as for attacking opponents and obtaining preferential access to food (Dou et al. 2004). However, our study shows that the juvenile sea bass group structure (according to the triggering activity) was not influenced by the size structure under self-feeding conditions. This group structure seems to be very stable and self-organised even after the removal of the regular feed-demand leader (Di-Poï et al. 2007; Millot and Bégout 2009) or chronic and acute stress experiments (Millot et al. 2010, 2011). In all cases, these changes were followed by the reconstruction of the group with the same structure and function as the initial group (Di-Poï et al. 2008).

In low and high $C V_{\mathrm{w}}$ groups, HT fish showed similar culture performances as the other fish, which confirmed results obtained by previous authors (Di-Poï et al. 2007, 2008; Millot et al. 2008). Covès et al. (2006) also showed that HT sea bass did not monopolize the trigger or the distributed pellets, therefore indicating that they were not displaying hierarchy. This could explain why the group structure was not influenced by the size structure. It should be remembered that the self-feeder was regulated to provide tanks with a reward level optimizing feed allocation to the group, and that direct competition for food only occurs when food is limited and defensible (Karplus et al. 2000). There is a need for further behavioural research in order to better understand the link between size-based social structure, and group structure according to triggering activity. For instance, it would be interesting to induce competition by restricting food delivery under self-feeding conditions, and to look at the influence of these two overlapping constraints on feed demand and social interactions.

Finally, all measured physiological variables were very similar in both low and high $C V_{\mathrm{w}}$ groups, and were within the usual values for sea bass (Coeurdacier et al. 1997; Dosdat et al. 2003; Millot et al. 2008) indicating that no important physiological changes were promoted by the population heterogeneity.

\section{Conclusion}

In the light of these results, it appears that grading practices, which are common in fish farming, induce only a transient modification of feed demand behaviour under selffeeding conditions. Juvenile sea bass seemed to adapt very quickly to new situations occurring in self-feeding conditions, including modifications in the size distribution of the population. The stability of the social structure built up around the self-feeder devices already known to be better in terms of feed conversion (Azzaydi et al. 1998), constitutes a new argument for their use (instead of automatic-feeders) Furthermore, grading practice does not improve the growth of graded fish in selffeeding conditions and the remarkable stability of $C V_{\mathrm{W}}$ over time indicates that size-grading frequency could be largely reduced, not only to avoid social structure disturbances but also to limit handling which is a labour-intensive and costly procedure.

Acknowledgements. We are grateful to the Aquanord company for providing animals. We also thank all the students from Ifremer L'Houmeau for their precious technical help during this experiment. We would finally like to thank Sandie Millot and Christophe Féron for statistical help. This study was conducted under the approval of the Animal Care Committee of France under the official licence of M.L. Bégout (17-010). 


\section{References}

Abbot J.C., Dill L.M., 1989, The relative growth of dominant and subordinate juvenile steelhead trout (Salmo gairdneri) fed equal rations. Behaviour 108, 104-113.

Abbot J.C., Dunbrack R.L., Orr C.D., 1985, The interaction of size and experience in dominance relationships of juvenile steelhead trout (Salmo gairdneri). Behaviour 92, 241-253.

Adams C.E., Huntingford F.A., Turnbull J.F., Beattie C., 1998, Alternative competitive strategies and the cost of food acquisition in juvenile Atlantic salmon (Salmo salar). Aquaculture 167, $17-26$.

Alanärä A., Brännäs E., 1993, A test of individual feeding activity and food size preference in rainbow trout using demand feeders. Aquac. Int. 1, 47-54.

Alanärä A., Brännäs E., 1996, Dominance in demand-feeding behaviour in Arctic charr and rainbow trout: the effect of stocking density. J. Fish Biol. 48, 242-254.

Aloisi D.B., 1994, Growth of hatchery-reared lake trout fed by demand feeders. Prog. Fish-Cult. 56, 40-43.

Anthouard M., Divanach P., Kentouri M., 1993, An analysis of feeding activities of sea bass Dicentrarchus labrax, Moronidae. raised under different lighting conditions. Ichthyophysiol. Acta 16, 5970.

Azzaydi M., Madrid J.A., Sánchez-Vázquez F.J., Martínez F.J., 1998, Effect of feeding strategies (automatic, ad libitum demand feeding and time-restricted demand-feeding) on feeding rhythms and growth in European sea bass (Dicentrarchus labrax L.). Aquaculture 163, 285-296.

Azzaydi M., Martínez F.J., Zamora S., Sánchez-Vázquez F.J., Madrid J.A., 1999, Effect of meal size modulation on growth performance and feeding rhythms in European sea bass (Dicentrarchus labrax L.). Aquaculture 170, 253-266.

Baardvik B.M., Jobling M.S., 1990, Effect of size-sorting on biomass gain and individual growth rates in Arctic charr, Salvelinus alpinus L. Aquaculture 90, 11-16.

Barki A., Haepaz S., Hulata G., Karpus I., 2000, Effects of larger fish and size grading on growth and size variation in fingerling silver perch. Aquac. Int. 8, 391-401.

Bégout-Anras M.L., 1995, Demand-feeding behaviour of sea bass kept in ponds: diel and seasonal patterns, and influences of environmental factors. Aquac. Int. 3, 186-195.

Benhaïm D., Skúlason S., Hansen B.R., 2003, Behavioural variation in juvenile Arctic charr in relation to body size. J. Fish Biol. 62, 1326-1338.

Boujard T., Dugy X., Genner D., Gosset C., Grig G., 1992, Description of a modular, low cost, eater meter for the study of feeding behavior and food preferences in fish. Physiol. Behav. 52, 1101-1106.

Boujard T., Jourdan M., Kentouri M., Divanach P., 1996, Diel feeding activity and the effect of time-restricted self-feeding on growth and feed conversion in European sea bass. Aquaculture 139, 117 127.

Brännäs E., Alanärä A., 1993, Monitoring the feeding activity of individual fish with a demand feeding system. J. Fish Biol. 42, 209215.
Campéas A., Brun-Bellut J., Baras E., Kestemont P., Gardeur J.N., 2009, Growth heterogeneity in rearing sea bass (Dicentrarchus labrax): test of hypothesis with an iterative energetic model. Animal 3, 1299-1307.

Carmichael G.J., 1994, Effects of size-grading on variation and growth in channel catfish reared at similar densities. J. World Aquac. Soc. 25, 7-24.

Coeurdacier J.L., Pepin J.F., Fauvel C., Legall P., Bourmaud A.F., Romestand B., 1997, Alterations in total protein, IgM and specific antibody activity of male and female sea bass (Dicentrarchus labrax L., 1758) sera following injection with killed Vibrio anguillarum. Fish Shellfish Immunol. 7, 151-160.

Covès D., Beauchaud M., Attia J., Dutto G., Bouchut C., Bégout M.L., 2006, Long-term monitoring of individual fish triggering activity on a self-feeding system: An example using European sea bass (Dicentrarchus labrax). Aquaculture 253, 385-392.

Covès D., Gasset, E., Lemarié G., Dutto G., 1998, A simple way of avoiding feed wastage in European seabass, Dicentrarchus labrax, under self-feeding conditions. Aquat. Living Resour. 11, 395-401.

Cutts C.J., Metcalfe N.B., Taylor A.C., 1998, Aggression and growth depression in juvenile Atlantic salmon: the consequences of individual variation in standard metabolic rate. J. Fish Biol. 52, 10261037.

Dagnélie P., 1975, Théorie et méthodes statistiques. Applications agronomiques. Vol. II. Les méthodes de l'inférence statistique. Les Presses agronomiques, Gembloux.

Di-Poï C., Attia J., Bouchut C., Dutto G., Covès D., Beauchaud M., 2007, Behavioral and neurophysiological responses of European sea bass groups reared under food constraint. Physiol. Behav. 90, 559-566.

Di-Poï C., Beauchaud M., Bouchut C., Dutto G., Covès D., Attia J., 2008, Effects of high food demand fish removal in groups of juvenile sea bass (Dicentrarchus labrax). Can. J. Zool. 86, 10151023.

Dosdat A., Person-Le Ruyet J., Covès D., Dutto G., Gasset E., Le Roux A., Lemarié G., 2003, Effect of chronic exposure to ammonia on growth, food utilisation and metabolism of the European sea bass (Dicentrarchus labrax). Aquat. Living Resour. 16, 509_ 520 .

Dou S.Z., Masuda R., Tanaka M., Tsukamoto K., 2004, Size hierarchies affecting the social interactions and growth of juvenile Japanese flounder, Paralichthys olivaceus. Aquaculture 233, 237-249.

Drews C., 1993 The concept and definition of dominance in animal behaviour. Behaviour 125, 283-311.

Goldan O., Popper D., Karplus I., 1997, Management of size variation in juvenile gilthead sea bream ( Sparus aurata). I: Particle size and frequency of feeding dry and live food. Aquaculture 152, 181-190.

Grant J.W.A., 1997 Territoriality. In: Godin, J.G.J. (Ed.), Behavioural Ecology of Teleost Fishes. Oxford Univ. Press, Oxford, pp. 81103.

Griffiths S.W., Armstrong J.D., 2002, Kin-biased territory overlap and food sharing among Atlantic salmon juveniles. J. Anim. Ecol. 71, $480-486$. 
Gunnes K., 1976, Effect of size grading young Atlantic salmon (Salmo salar) on subsequent growth. Aquaculture 9, 381-386.

Harrenstien L.A., Tornquist S.J., Miller-Morgan T.J., Fodness B.G., Clifford K.E., 2005, Evaluation of a point-of-care blood analyzer and determination of reference ranges for blood parameters in rockfish. J. Am. Vet. Med. Assoc. 226, 255-265.

Huntingford F.A., Metcalfe N.B., Thorpe J.E., 1993, Social status and feeding in Atlantic salmon Salmo salar parr: the effect of visual exposure to a dominant. Ethology 94, 201-206.

Huntingford F.A., Metcalfe N.B., Thorpe J.E., Graham W.D., Adams C.E., 1990, Social dominance and body size in Atlantic parr, Salmo salar L. J. Fish Biol. 36, 877-881.

Jobling M., 1985, Physiological and social constraints on growth of fish with special reference to Arctic charr, Salvelinus alpinus L. Aquaculture 44, 83-90.

Jobling M., Baardvick B.M., 1994, The influence of environmental manipulations on inter- and intra-inidivdual variation in food acquisition and growth performance of Arctic charr, Salvelinus alpinus. J. Fish Biol. 44, 1069-1087.

Jobling M., Jorgensen E.H., Arnesen A.M., Ringo E., 1993, Feeding, growth and environmental requirements of arctic charr: a review of aquaculture potential. Aquac. Int. 1, 20-46.

Jobling M., Wandsvik A., 1983, Effect of social interactions on growth rates and conversion efficiency of Arctic charr, Salvelinus alpinus L. J. Fish Biol. 22, 577-584.

Jørgensen E.H., Jobling M., 1990, Feeding modes in Arctic charr, Salvelinus alpinus L.: The importance of bottom feeding for the maintenance of growth. Aquaculture 86, 379-385.

Kamstra A., 1993, The effect of size grading on individual growth in eel, Anguilla anguilla, measured by individual marking. Aquaculture 112, 67-77.

Karplus I., Popper D., Goldan O., 2000, The effect of food competition and relative size of group members on growth of juvenile gilthead sea bream, Sparus aurata. Fish Physiol. Biochem. 22, 119-123.

Kestemont P., Jourdan S., Houbart M., Mélard C., Paspatis M., Fontaine P., Cuvier A., Kentouri M., Baras E., 2003, Size heterogeneity, cannibalism and competition in cultured predatory fish larvae: biotic and abiotic influences. Aquaculture 227, 333-356.

Koebele B.P., 1985, Growth and the size hierarchy effect: an experimental assessment of three proposed mechanisms; activity differences, disproportional food acquisition, physiological stress. Environ. Biol. Fishes 12, 181-188.

Lambert Y., Dutil J.-D., 2001, Food intake and growth of adult Atlantic cod (Gadus morhua L.) reared under different conditions of stocking density, feeding frequency and size-grading. Aquaculture 192, 233-247.

Lee E.M., 1988, Commercial cod farming operations, Newfoundland. Can. Ind. Rep. Fish. Aquat. Sci. 201.

Liao I.C., Chang E.Y., 2002, Timing and factors affecting cannibalism in red drum, Sciaenops ocellatus, larvae in captivity. Environ. Biol. Fishes 63, 229-233.

Magnuson J.J., 1962, An analysis of aggressive behavior, growth, and competition for food and space in medaka (Oryzias latipes Pisces, Cyprinodontidae). Can. J. Zool. 40, 313-363.
McCarthy I.D., Carter C.G., Houlihan D.F., 1992, The effect of feeding hierarchy on individual variability in daily feeding of rainbow trout, Oncorhynchus mykiss (Walbaum). J. Fish Biol. 41, 257263.

McDonald M.E., Tikkanen C.A., Axler R.P., Larsen C.P., Host G., 1996, Fish simulation culture model (FIS-C): A bioenergetics based model for aquacultural wasteload application. Aquac. Eng. $15,243-259$.

Mgaya Y.D., Mercer J.P., 1995, The effects of size grading and stocking density on growth performance of juvenile abalone, Haliotis tuberculata Linnaeus. Aquaculture 136, 297-312.

Millot S., Bégout M.-L., 2009, Individual fish rhythm directs group feeding: a case study with sea bass juveniles (Dicentrarchus labrax) under self-demand feeding conditions. Aquat. Living Resour. 22, 363-370.

Millot S., Bégout M.-L., Chatain B., 2009, Exploration behaviour and flight response toward a stimulus in three sea bass strains (Dicentrarchus labrax L.). Appl. Anim. Behav. 119, 108-114.

Millot S., Bégout M.-L., Person-Le Ruyet J., Breuil G., Di-Poï C., Fievet J., Pineau P., Roué M., Sévère A., 2008, Feed demand behavior in sea bass juveniles: effects on individual specific growth rate variation and health (inter-individual and intergroup variation). Aquaculture 274, 87-95.

Millot S., Péan S., Chatain B., Bégout M.L., 2011, Self-feeding behavior changes induced by a first and a second generation of domestication or selection for growth in the European sea bass, Dicentrarchus labrax. Aquat. Living Resour. 24, 53-61.

Millot S., Péan S., Leguay D., Vergnet A., Chatain B., Bégout M.L., 2010, Evaluation of behavioral changes induced by a first step of domestication or selection for growth in the European sea bass (Dicentrarchus labrax): A self-feeding approach under repeated acute stress. Aquaculture 306, 211-217.

Muller-Feuga A., 1998, Growth as a function of rationing: a model applicable to fish and microalgae. J. Exp. Mar. Biol. Ecol. 236, $1-13$.

Øverli Ø., Winberg S., Damsård B., Jobling M., 1998, Food intake and spontaneous swimming activity in Arctic char (Salvelinus alpinus): role of brain serotonergic activity and social interactions. Can. J. Zool. 76, 1366-1370.

Overton J.L., Steenfeldt S.J., Pedersen P.B., 2010, The effects of grading on the growth and survival of juvenile Dover sole (Solea solea L.). Aquac. Res. 42, 31-39.

Pickering A.D., 1981, Introduction: The concept of biological stress. In: Stress and Fish. Academic Press, London and New York, pp. $1-9$.

Rubenstein D.I., 1981, Individual variation and competition in the Everglades pygmy sunfish. J. Anim. Ecol. 50, 337-350.

Rubio V.C., Sánchez-Vázquez F.J., Madrid J.A., 2003, Nocturnal feeding reduces sea bass (Dicentrarchus labrax L.) pelletcatching ability. Aquaculture 220, 697-705.

Rubio V.C., Vivas M., Sanchez-Mut A., Sanchez-Vazquez F.J., Coves D., Dutto G., Madrid J.A., 2004, Self-feeding of European sea bass (Dicentrarchus labrax, L.) under laboratory and farming conditions using a string sensor. Aquaculture 233, 393-403.

Sánchez-Vázquez F.J., Azzaydi M., Martinez F.J., Zamora S., Madrid J.A., 1998, Annual rhythms of demand-feeding activity in sea 
bass: evidence of a seasonal phase inversion of the diel feeding pattern. Chronobiol. Int. 15, 607-622.

Sánchez-Vázquez F.J., Madrid J.A., Zamora S., 1995, Circadian rhythms of feeding activity in sea bass, Dicentrarchus labrax L.: dual phasing capacity of diel demand-feeding pattern. J. Biol. Rhythms 10, 256-266.

Sánchez-Vázquez F.J., Martinez M., Zamora S., Madrid J.A., 1994, Design and performance of an accurate demand feeder for the study of feeding behaviour in sea bass, Dicentrarchus labrax L. . Physiol. Behav. 56, 789-794.

Sloman K.A., Armstrong J.D., 2002, Physiological effects of dominance hierarchies: laboratory artefacts or natural phenomena? J. Fish Biol. 61, 1-23.

Smith M.E., Fuiman L.A., 2003, Causes of growth depensation in red drum, Sciaenops ocellatus, larvae. Environ. Biol. Fishes 66, 4960.

Stefánsson M.Ö., Imsland A.K., Jenssen M.D., Jonassen T.M., Stefansson S.O., Fitzgerald R., 2000, The effect of different initial size distributions on the growth of Atlantic halibut. J. Fish Biol. $56,826-836$.
Strand H.K., Øiestad V., 1997, Growth and the effect of grading, of turbot in a shallow raceway system. Aquac. Int. 5, 397-406.

Sunde L.M., Imsland A.K., Folkvord A., Stefansson S.O., 1998, Effects of size grading on growth and survival of juvenile turbot at two temperatures. Aquac. Int. 6, 19-32.

Volkoff H., Peter R.E., 2006, Feeding behavior of fish and its control. Zebrafish 3, 131-140.

Wallace J.C., Kolbeinshavn A.G., 1988, The effect of size grading on subsequent growth in fingerling Arctic charr, Salvelinus alpinus. Aquaculture 73, 97-100.

Ward A.J.W., Webster M.M., Hart P.J.B., 2006, Intraspecific food competition in fishes. Fish Fish. 7, 231-261.

Yamagishi H., Maruyama T., Mashiko K., 1974, Social relation in a small experimental population of Odontobutis obscurus (Temminck et Schlegel) as related to individual growth and food intake. Oecologia 17, 187-202.

Zar J.H., 1984, Biostatistical analysis, 2nd editors, Prentice Hall, Englewood Cliffs. 